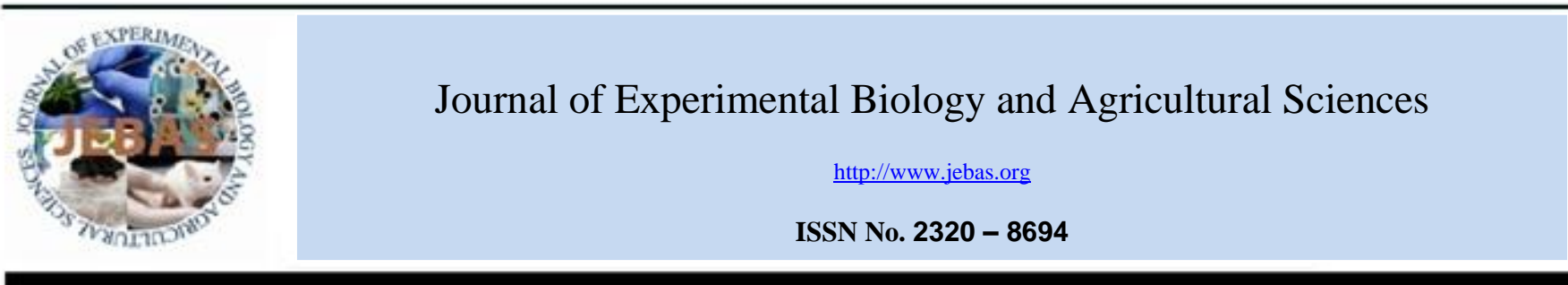

\title{
ROLE OF INTERLEUKIN-2, INTERLEUKIN-4 AND CLUSTER OF DIFFERENTIATION-22 AS AN IMMUNE MARKERS IN INDIVIDUALS INFECTED WITH Helicobacter pylori
}

\author{
Jaffar Muhammad Baqir Muhammad Rashad, Ahmed Abdul jabbar Jaloob Aljanaby*
}

Department of biology, Faculty of Science, University of Kufa, Iraq

Received - May 17, 2021; Revision - June 09, 2021; Accepted - June 22, 2021

Available Online - June 25, 2021

DOI: http://dx.doi.org/10.18006/2021.9(3).388.393

KEYWORDS
Helicobacter pylori
Immune response
IL-2
IL-4
CD22
Iraq

* Corresponding author

E-mail: ahmedaj.aljanabi@uokufa.edu.iq (Ahmed Abduljabbar Jaloob Aljanaby)

Peer review under responsibility of Journal of Experimental Biology and Agricultural Sciences.

Production and Hosting by Horizon Publisher India [HPI] (http://www.horizonpublisherindia.in/).

All rights reserved.

\begin{abstract}
Helicobacter pylori is a gram-negative, intracellular, microaerophilic bacteria which causing Peptic ulcer. This bacterium can change its shape which helps the bacteria to survive in the host gastric microenvironment. The Peptic ulcer caused by this bacterium stimulates the humoral and cellular immune response in individuals. The current study was carried out to access the role of interleukin-2, interleukin-4, and cluster differentiation-22 as immune markers in the identification of $H$. pylori infection. The presence of $H$. pylori has been diagnosed by feces test (antigen rapid test). In this study, the presence of three immunological markers viz., IL-2, IL-4, and CD22 were measured in the serum of 60 individuals infected with $H$. pylori and 30 healthy individuals by the Enzyme-Linked Immunesorbent Assay method. Results of this study indicated a significant increase $\left(\mathrm{P}\right.$-value $\left.=0.0307^{*}\right)$ in the concentration of IL-2 $(294.27 \mathrm{ng} / \mathrm{ml})$, IL-4 $(151.28 \mathrm{ng} / \mathrm{ml})$, and CD22 $(492.73 \mathrm{ng} / \mathrm{ml})$ in the serum of individuals infected with $H$. pylori while these concentrations were reported $235.98 \mathrm{ng} / \mathrm{ml}, 116.14 \mathrm{ng} / \mathrm{ml}$ and $369.33 \mathrm{ng} / \mathrm{ml}$ respectively in the healthy individuals. Results of the study can be concluded that H.pylori infection stimulates the Cellular and humoral immune response which resulted in the increased production of IL-2, IL-4, and CD22.
\end{abstract}

All the articles published by Journal of Experimental Biology and Agricultural Sciences are licensed under a Creative Commons Attribution-NonCommercial 4.0 International License Based on a work at www.jebas.org.

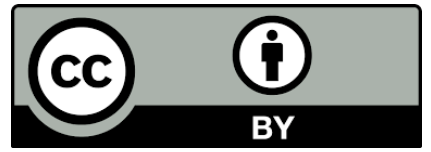




\section{Introduction}

Helicobacter pylori is a spiral, microaerophilic, noninvasive, gramnegative bacterium that colonizes in the human gastrointestinal tract, primarily in the stomach (Mohammadian \& Ganji, 2019). It is a well-known gastric pathogen that affects almost half of the world's population, around 4.4 billion individuals globally affected by the infection of this bacterium, and maximum of these are from developing countries (Kusters et al., 2006; Hamzah \& Aljanaby, 2020; Reshetnyak et al., 2021). This organism has been identified as an etiological agent for chronic active gastritis, peptic ulcer disease, gastric adenocarcinoma, and mucosa-associated lymphoid tissue (MALT) lymphoma (Hathroubi et al., 2018). The infection of $H$. pylori normally start in infancy and remained throughout life, is leading to serious infections such as gastric carcinoma, duodenum ulcer, gastritis, and gastric ulcer in adults, which are mostly transferred from person to person through saliva, vomit, and fecal matter, very rarely it transferred by the contaminated water and drink (Razavi et al., 2015; Qumar et al., 2021). Various factors such as the vacuolating cytotoxin, the cagA and cag pathogenicity island (cagPAI), motility, adhesins, and the urease enzyme are known to be involved in the virulence of this organism (Dunn et al., 1997). The World Health Organization and the International Agency for Research on Cancer (IARC) have identified H. pylori as a type I carcinogen linked to the development of gastric cancer (GC) since 1994 and it is closely linked with the environment, diet, and gene mutations (Hatakeyama, 2014). Furthermore, H. pylori may create biofilms to reduce its sensitivity to a variety of antibiotics such as Amoxicillin, Tetracycline, and Ceftriaxone, resulting in multi-drug resistance (MDR), mutations, and further bacterial eradication challenges (Liu et al., 2021a). H. pylori can form biofilms on the human gastric mucosa also. Moreover, $H$. pylori could embed in drinking water and formed biofilms in the water or on the surfaces of water distribution systems in developed and developing countries. Therefore, a more thorough understanding of $H$. pylori biofilm could be helpful in the characterization of this microorganism (Guillermo et al., 2020). Early-stage identification of $H$. pylori might help in the proper management of $H$. pylori (Suarez et al., 2006; Xu et al., 2020). Jung et al. (2020) suggested that humans afflicted with $H$. pylori produced specific antibodies, which can be detected in serum as well as gastric aspirates or stomach extracts, this phenomenon can be helpful in the diagnosis of $H$. pylori infection. Further, this bacterium also triggers the immune reactions in the infected organism. The most common test to detect $H$. pylori is the stool antigen test that looks for foreign proteins (antigens) associated with $H$. pylori infection in patients stool. Furthermore, other tests like a breath test, scope test, and stool PCR can also be used for the identification of $H$. pylori infection (Guillermo et al., 2020). The immune response caused by $H$. pylori is a topic of ongoing research that has prompted a slew of questions (Alipour, 2020). The host's failure to clear H. pylori infections might be due to down regulatory processes that limit the subsequent immune responses to suppress dangerous inflammation as a way of protecting the host (Bravo et al., 2018). As a result, the mediated chronic immune response could be insufficient or misdirected, creating a colonization benefit for the bacteria by increasing the availability of adhesion sites (Săsăran et al., 2021). Information regarding the immune response in the H. pylori infected patients in Iraq are in scanty. Therefore, the current study was carried out to establish the relationship between humoral and cellular immune responses in $H$. pylori infected individuals.

\section{Materials and Methods}

\subsection{Respondent and Study design}

This case-control study was carried out at Al-Kufa City, Iraq from September 2020 to February 2021. A total of $60 \mathrm{H}$. pylori infected patients and 30 healthy (as control) male and female age range 2060 years old were included in this study. H. pylori infected patients were admitted to the middle Euphrates hospital in Al-Kufa city. Before starting the study, the written consent and ethical approval were taken from all the selected individuals.

\subsection{Detection of $\boldsymbol{H}$. pylori by Feces Test (Antigen rapid test)}

The readymade kit was used for immune-chromatographic assay and qualitative determination of $H$. pylori antigen in feces. The test was carried out as per the manufacturer's instruction (EDI, EPITOPE, diagnostic, INC, United States).

\subsection{Measurement of IL-2, IL-4, and CD22 concentration by enzyme linked immunosorbent assay (ELISA)}

This test was conducted according to the manufacturing company instructions (Bioassay Technology Laboratory. Shanghai, China). Five $\mathrm{ml}$ of blood sample were collected from all the individuals and $2 \mathrm{ml}$ of serum for each individual has been obtained by centrifugation at $8000 \mathrm{rpm} / 10 \mathrm{~min}$. This serum concentration has been used for the measurement of IL-2, IL-4, and CD22 by the enzyme-linked immunosorbent assay (ELISA).

\subsection{Statistical analysis}

The statistical analysis was carried out by using the computer software (graph pad prism version 6) and a mean value and standard error (SE) have been obtained for each value. Statistically significant $\mathrm{P}$ values less than 0.05 were considered for the statistical analysis (Aljanaby \& Medhat, 2017; Aljanaby \& Aljanaby, 2018; Atif et al., 2021). 


\section{Results}

\subsection{Total patients, their gender, and age groups}

Out of 60 patients, the results of the present study demonstrated that there were 27 males $(45 \%)$ and 33 females (55\%) were infected by H.pylori (Figure 1). Among these, a maximum of 21 patients (35\%) infected by $H$. pylori belonged to the age group of 51-60 years, followed by the age group of 41-50 years (15 patients), 31- 40 years (14 patients) and 20-30 years (10 patients) (Table 1).

\subsection{Immunological markers}

Results related to humeral and cellular immunity revealed that H.pylori infection increased the concentration of IL2, IL4, and
CD22, and this concentration was significantly higher than the control. Further, the concentration of IL-2, IL4, and CD22 in individuals infected with $H$. pylori was reported $294.27 \mathrm{ng} / \mathrm{ml}$, $151.28 \mathrm{ng} / \mathrm{ml}$, and $492.73 \mathrm{ng} / \mathrm{ml}$, and these concentrations were significantly higher than the healthy individual where these concentrations were reported $235.98 \mathrm{ng} / \mathrm{ml}, 116.14 \mathrm{ng} / \mathrm{ml}$ and $369.33 \mathrm{ng} / \mathrm{ml}$ respectively (Figure 2,3 \& 4).

\section{Discussions}

The results of the current investigation suggested that there is a substantial connection between IL-2 and $H$. pylori infection. Further, a cytokine like IL-2 has remarkable beneficial impacts on the immune system and this type of interleukin can be used to treat both metastatic renal cell carcinoma and metastatic melanoma (Buchbinder et al. 2019). The discovery of IL-2 as a "T-cell

Table1 Numbers and percentages of patients infected with H.pylori according to age groups

\begin{tabular}{|ccccc}
\hline Age groups (years) & Male & Female & Total (\%) & $10(16.6)$ \\
\hline $20-30$ & 5 & 5 & $14(23.4)$ \\
\hline $31-40$ & 7 & 9 & $15(25)$ \\
\hline $41-50$ & 6 & 12 & $21(35)$ \\
\hline $51-60$ & 9 & 33 & $60(100 \%)$ \\
\hline Total & 27 & & \\
\hline
\end{tabular}

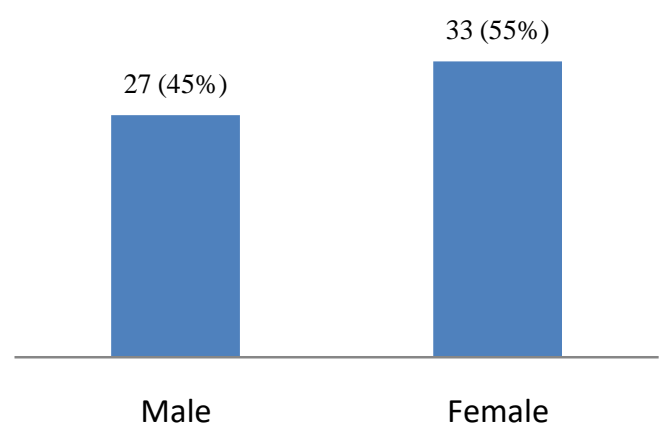

Figure 1 Male and female individuals infected with H.pylori

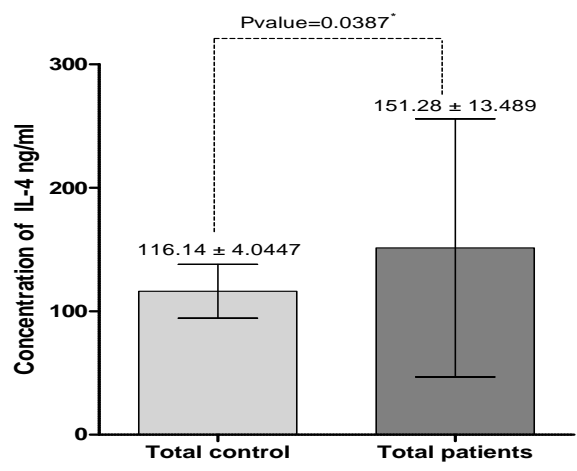

Figure 3 The concentration of IL-2 in H. Pylori infected and healthy individuals

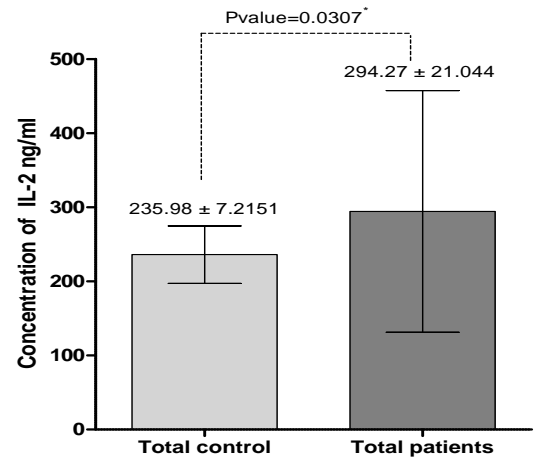

Figure 2 The concentration of IL-2 in H. Pylori infected and healthy individuals

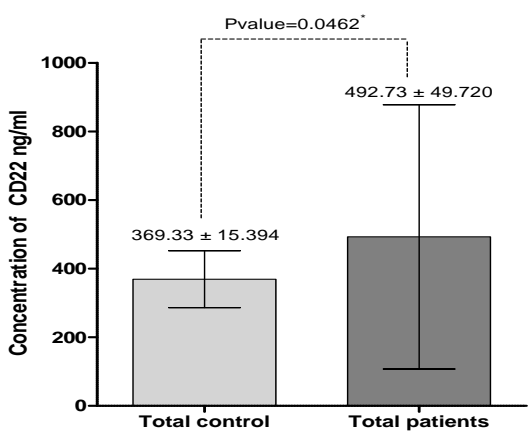

Figure 4 The concentration of CD22 in H. Pylori infected and healthy individuals

Journal of Experimental Biology and Agricultural Sciences http://www.jebas.org 
growth factor" (TCGF) in 1976 was an extremely major milestone in immunology and is the foundation for most of the immunotherapy used in human cancers (Leko \& Rosenberg, 2020; Liu et al., 2021b). Further, T cells release interleukin-2, which is a strong immunoregulatory cytokine implicated in cell-mediated immunity, when it triggered by mitogens or by interacting with antigen or major histocompatibility complexes of antigenpresenting cells, and it works as a T-cell growth factor (Davinelli et al., 2019). Lymphocyte cell (T- helper 2) cells produce IL-4, IL5, IL-6, and IL-10, which activate and develop B cells, while Thelper1 cells produce IL-2 and interferon (IFN-gamma), which boost cell-mediated immune responses (Wong et al., 2015). Interleukin-2 is a strong $\mathrm{T}$ cell proliferation factor, and it was swiftly embraced for cancer immunotherapy, especially in the treatment of metastatic melanoma and renal cell carcinoma (Ross \& Cantrell, 2018).

The results proved that there was a significant increase in IL-4 level in serum of patients infected with H.pylori as compared with healthy individuals. $T$ cell activation, differentiation, proliferation, and survival are well regulated by interleukin- 4 in diverse $\mathrm{T}$ cell types (Silva-Filho et al., 2014). Further, T-helper 2 also generates IL-4, which has an immune-modulatory impact on B cells, mast cells, macrophages, and a variety of other cell types. Along with this, IL-4 is an important element in the formation of Th2 cells, which release cytokines that cause allergic reactions (Steinke \& Borish, 2001). Because of its ability to reduced inflammation and lower serotonin transporter activity, interleukin 4 mainly cytokine type Th2 may protect the cell against bacterial infections (Schneider et al., 2001). The $H$. pylori neutrophil-activating protein (HP-NAP) is one of the numerous bacterial factors that not only drives Th1 inflammation but also inhibits $\mathrm{Th} 2$ responses in humans in vivo (Guo et al. 2020). Interleukin-4, therefore, plays a key role in humoral and cell-mediated immunity, demonstrating antiinflammatory effects through up-regulated cytokine inhibitors and scavenger receptors, as well as improving Th2 mediated immunity (CortesSelva et al., 2019).

B cell response to antigens like H.pylori and innate immune signals are influenced by the Cluster of differentiation-22. As a result, interactions between $\mathrm{CD} 22$ and $\mathrm{CD} 22 \mathrm{~L}$ are critical for sustaining self-tolerance (Fan et al., 1994). In the current study, a substantial rise in serum CD22 levels was reported in the individuals infected with H.pylori. CD22 capacity to modulate both B-cells and T-cell receptors may be used to manipulate B cell responses to H.pylori infection (Fry et al., 2018). Differentiation cluster-22 positive lamina propria lymphocytes have been seen in H.pylori-positive people. These data imply that antigenic responses to H.pylori are significantly decreased in H.pylori positive individuals, perhaps indicating antigenic suppression activation (Salar, 2019).

\section{Conclusions}

Results of the study can be concluded that infection of $H$. pylori elevated the level of three immunological markers viz., IL-2, IL-4, and CD22 in human beings, and this will be helpful in the early diagnosis of $H$. pylori infection. Further, it was reported that $H$. pylori infected people have higher activities of B cell and T helper cells.

\section{Conflict of Interest}

This study does not have any conflict of interest

\section{Source of Funding}

There was no fund in this study, fund by authors themselves

\section{References}

Alipour M (2020) Molecular Mechanism of Helicobacter pylori Induced Gastric Cancer. Journal of Gastrointestinal Cancer 52: $23-$ 30

Aljanaby AAJ, Aljanaby IA (2018) Prevalence of aerobic pathogenic bacteria isolated from patients with burn infection and their antimicrobial susceptibility patterns in Al-Najaf City, Iraq-a three-year cross-sectional study. F1000Research 7:1157.

Aljanaby AAJ, Medhat AR (2017) Research article prevalence of some antimicrobials resistance associated-genes in Salmonella typhi isolated from patients infected with typhoid fever. International Journal of Biological Sciences 17(4):171-84.

Atif FA, Hussain K, Qamar MF, Sajid MS, Arfan M (2021) First Report on Transplacental Transmission of Anaplasmamarginale in Neonatal Dairy Calves from District Jhang, Punjab, Pakistan. International Journal of Agriculture and Biology 25 (3): 541-546.

Bravo D, Hoare A, Soto C, Valenzuela MA, Quest AF (2018) Helicobacter pylori in human health and disease: Mechanisms for local gastric and systemic effects. World Journal of Gastroenterology 24(28):3071. doi: 10.3748/wjg.v24.i28.3071.

Buchbinder EI, Dutcher JP, Daniels GA, Curti BD, Patel SP, Holtan SG, Miletello GP, Fishman MN, Gonzalez R, Clark JI, Richart JM (2019) Therapy with high-dose Interleukin-2 (HD IL-2) in metastatic melanoma and renal cell carcinoma following PD1 or PDL1 inhibition. Journal for Immunotherapy of Cancer 7(1):1-7.

Cortes-Selva D, Ready A, Gibbs L, Rajwa B, Fairfax KC (2019) IL-4 promotes stromal cell expansion and is critical for development of a type-2, but not a type 1 immune response. European Journal of Immunology 49(3):428-42. 
Davinelli S, Melvang HM, Andersen LP, Scapagnini G, Nielsen ME (2019) Astaxanthin from shrimp cephalothorax stimulates the immune response by enhancing IFN- $\gamma$, IL-10, and IL-2 secretion in splenocytes of Helicobacter pylori infected mice. Marine Drugs 17(7):382.

Dunn BE, Cohen H, Blaser MJ (1997) Helicobacter pylori. Clinical Microbiology Reviews 10(4): 720-741.

Fan XJ, Chua A, Shahi CN, McDevitt J, Keeling PW, Kelleher D (1994) Gastric T lymphocyte responses to Helicobacter pylori in patients with H pylori colonisation. Gut Journal 35(10):1379-84.

Fry TJ, Shah NN, Orentas RJ, Stetler-Stevenson M, Yuan CM, Ramakrishna S, Wolters P, Martin S, Delbrook C, Yates B, Shalabi $\mathrm{H}$ (2018) CD22-targeted CAR T cells induce remission in B-ALL that is naive or resistant to CD19-targeted CAR immunotherapy. Nature Medicine 24(1):20.

Guillermo Espinoza-Contreras J, Idalia Torres-Ruiz M, Ariel Waller-González L, De JesúsRamírez-García J, Torres-López J, Ventura-Juárez J, Verónica Moreno-Córdova E, Ernesto LópezRamos J, Humberto Muñoz-Ortega M, Eugenia Vargas-Camaño M, González-Segovia R (2020) Immunological markers and Helicobacter pylori in patients with stomach cancer: Expression and correlation. Biomedical reports 12(5):233-243.

Guo X, Ding C, Lu J, Zhou T, Liang T, Ji Z, Xie P, Liu X, Kang Q (2020) HP-NAP ameliorates OXA-induced atopic dermatitis symptoms in mice. Immunopharmacology and Immunotoxicology 42(5):416-22.

Hamzah DN, Aljanaby AAJ (2020) Immune response in patients infected with Helicobacter pylori in Al-Najaf City, Iraq International Journal of Pharmaceutical Sciences Research 12(3): 901-911.

Hatakeyama M (2014) Helicobacter pylori CagA and gastric cancer: a paradigm for hit-and-run carcinogenesis. Cell host \& Microbe15(3):306-16.

Hathroubi S, Servetas SL, Windham I, Merrell DS, Ottemann KM (2018) Helicobacter pylori biofilm formation and its potential role in pathogenesis. Microbiology and Molecular Biology Reviews 82(2):e00001-18.

Jung HK, Kang SJ, Lee YC, Yang HJ, Park SY, Shin CM, Kim SE, Lim HC, Kim JH, Nam SY, Shin WG (2020) Evidence-based Guidelines for the Treatment of Helicobacter pylori Infection in Korea. The Korean Journal of Helicobacter and Upper Gastrointestinal Research 20(4):261-87.
Kusters JG, van Vliet AH, Kuipers EJ (2006) Pathogenesis of Helicobacter pylori infection. Clinical Microbiology Reviews 19(3): 449-490.

Leko V, Rosenberg SA (2020) Identifying and targeting human tumor antigens for $\mathrm{T}$ cell-based immunotherapy of solid tumors. Cancer Cell 38(4):454-472.

Liu W, Tian J, Hui W, Kong W, Feng Y, Si J, Gao F (2021a) A retrospective study assessing the acceleration effect of type I Helicobacter pylori infection on the progress of atrophic gastritis. Scientific Reports 11(1):1-6.

Liu Y, Zhou N, Zhou LI, Wang J, Zhou Y, Zhang T, Fang Y, Deng J, Gao Y, Liang X, Lv J (2021b) IL-2 regulates tumor-reactive CD8+ $\mathrm{T}$ cell exhaustion by activating the aryl hydrocarbon receptor. Nature Immunology 22(3):358-69.

Mohammadian T, Ganji L (2019) The Diagnostic Tests for Detection of Helicobacter pylori Infection. Monoclonal Antibodies in Immunodiagnosis and Immunotherapy 38(1):1-7.

Qumar S, Nguyen TH, Nahar S, Sarker N, Baker S, Bulach D, Ahmed N, Rahman M (2021) A comparative whole genome analysis of Helicobacter pylori from a human dense South Asian setting. Helicobacter 26(1):e12766. https://doi.org/10.1111/hel.12766.

Razavi A, Bagheri N, Azadegan-Dehkordi F, Shirzad M, Rahimian G, Rafieian-Kopaei M, Shirzad H (2015) Comparative immune response in children and adults with $H$. pylori infection. Journal of Immunology Research 2015: 315957. doi: 10.1155/2015/315957.

Reshetnyak VI, Burmistrov AI, Maev IV (2021) Helicobacter pylori: Commensal, symbiont or pathogen?. World Journal of Gastroenterology 27(7):545.

Ross SH, Cantrell DA (2018) Signaling and function of interleukin-2 in T lymphocytes. Annual Review of Immunology $36: 411-33$.

Salar A (2019) Gastric MALT lymphoma and Helicobacter pylori. Medicina Clínica 152(2):65-71.

Săsăran MO, Meliț LE, Dobru ED (2021) MicroRNA Modulation of Host Immune Response and Inflammation Triggered by Helicobacter pylori. International Journal of Molecular 22(3): 1406 .

Schneider E, Machavoine F, Bricard-Rignault R, Levasseur M, Petit-Bertron AF, Gautron S, Ribeil JA, Launay JM, Mecheri S, Côté F, Dy M (2001) Downregulation of basophil-derived IL-4 and in vivo $\mathrm{TH} 2 \mathrm{IgE}$ responses by serotonin and other organic cation transporter 3 ligands. The Journal of Allergy and Clinical Immunology 128(4):864-71. 
Silva-Filho JL, Caruso-Neves C, Pinheiro AA (2014) IL-4: an important cytokine in determining the fate of $\mathrm{T}$ cells. Biophysical reviews 6(1):111-8.

Steinke JW, Borish L (2001) Th2 cytokines and asthmaInterleukin-4: its role in the pathogenesis of asthma, and targeting it for asthma treatment with interleukin-4 receptor antagonists. Respiratory Research 2(2):1-5.

Suarez G, Reyes VE, Beswick EJ (2006) Immune response to $H$ pylori. World Journal of Gastroenterology 12(35):5593.

Wong M, Huang P, Li W, Li Y, Zhang SS, Zhang C (2015) Thelper1/T-helper2 cytokine imbalance in the iris of patients with glaucoma. PLoS One 10(3):e0122184.

Xu C, Soyfoo DM, Wu Y, Xu S (2020) Virulence of Helicobacter pylori outer membrane proteins: An updated review. European Journal of Clinical Microbiology \& Infectious Diseases 17:1-0. 